Преводна статия от Европейското списание по болнична фармация, публикувана с разрешение на Европейската асоциачия на болничните фармацевти (ЕАНP)

The original source of this article is: Valeria Vinciguerra, Annie Fagot-Gandet and Cyril Boronad. A clinical audit of sterile medical devices: a French experience of quality and safetyimprovement in hospital services. Eur J Hosp Pharm 2016 23: 134-140

doi: 10.1136/ejhpharm-2015-000739

\title{
A CLINICAL AUDIT OF STERILE MEDICAL DEVICES: A FRENCH EXPERIENCE OF QUALITY AND SAFETY IMPROVEMENT IN HOSPITAL SERVICES
}

Valeria Vinciguerra $^{1}$, Annie Fagot-Gandet ${ }^{2}$, Cyril Boronad ${ }^{2}$

${ }^{I}$ Specialization School in Hospital Pharmacy, University of the Studies of Turin, Turin, Italy

${ }^{2}$ Hospital Centre of Cannes (Centre Hospistalier de Cannes-CH Cannes), Cannes, France

\section{КЛИНИЧЕН ОДИТ НА СТЕРИЛНИ МЕДИЦИНСКИ ИЗДЕЛИЯ: ПРИМЕРИ ОТ ФРАНЦИЯ ЗА ПОДОБРЯВАНЕ НА КАЧЕСТВОТО И БЕЗОПАСНОСТТА НА БОЛНИЧНИТЕ УСЛУГИ}

\author{
Валериа Винцигуера ${ }^{1}$, Ани Фагот-Ганде ${ }^{2}$ Сирил Борнар ${ }^{2}$ \\ ${ }^{l}$ Училище за специализанти в Болнична аптека, Университет по проучванията на Торино, \\ Торино, Италия \\ ${ }^{2}$ Болничен цеентър на Кан, Кан,Франция
}

\begin{abstract}
Резюме.
Цели: Инспектиране на качеството и безопасността при управлението на стерилни медицински изделия (СМИ) за определяне на ролята на фрармацевта в един мултидисциплинарен екип и за представяне на пример на оценка на дейностите, свързани със СМИ от страна на болничния персонал.
\end{abstract}

Mетоди: Оценяването на дейностите, свързани със СМИ се извърши с помощта на инструмента на Националната агенция за подкрепа на работата на здравните и медико-социалните заведения (ANAP, на фpp. Agence Nationale d'Appui à la Performance des établissements de santé et médico-sociaux) в Болничния център в Кан, Франция, през август 2013 г. Четирима здравни специалисти и трима болнични фрармацевти направиха оценка на цикъла на СМИ в здравното заведение, цикъла на СМИ и медицинските практики в отделението за коремна, съдова и урологична хирургия. Бяха анализирани общо 1850 заявки за ползване на СМИ за болничната аптека и 1110 за отделението. Категориите за степен на контрол на риска бяха определени както следва: 0-33\% - „ниска степен“, 34-66\% „средна степен“ и 67-100\% - „висока степен“. Резултати: Контролът на риска за политиката за безопасността в лечебното заведение се определи като „висок“ (67\%), за цикъла на СМИ в болничната аптека и в отделението съответно като „висок“ (68\%) и „среден“ (64\%), и за медицинските практики като „висок“ (88\%). И за двете услуги се получиха добри резултати.

Заключения: Изследвани бяха стандартите за безопасност и качество, като се установи изпълнение на последните. По отношение на обучението на здравните работници, информацията относно и наличието на подробни процедури за политика за безопасност и медицински практики резултатите бяха добри. Основните слабости бяха дефицит в осигуряването на ИТ 
и липсата на процедури по отношение на цикъла на СМИ. Демонстрирано беше, че болничният фармацевт е ключова фицура в мултидисциплинарния екип.

\section{Abstract.}

Objectives: To audit the quality and safe management of sterile medical devices (SMDs), to examine the pharmacist's role in a multidisciplinary team, and to provide an example of hospital staff assessment of SMDs.

Methods: SMD management was assessed using the National Agency for Support to the Performance of Health and Medical-Social Establishment tool in the Hospital Centre of Cannes, France, in August 2013. Safety policy in the healthcare establishment, and the SMD cycle in the hospital pharmacy, SMD cycle and care practices in the visceral-vascular-urological surgery care unit were evaluated by four health professionals and three hospital pharmacists. A total of 1850 references to SMDs for the hospital pharmacy and 1110 references to SMDs for the care unit were analysed. The percentage of risk control was defined as: 0-33\% 'low', 34-66\% 'medium', 67-100\% 'high'.

Results: Risk control was 'high' (67\%) for the safety policy in the health establishment, 'high' (68\%) and 'medium' (64\%) for the SMD cycle in the hospital pharmacy and the care unit, respectively, and 'high' (88\%) for the care practices. Good scores were obtained in both services.

Conclusions: Safety and quality standards were investigated, and satisfied. Training of health professionals and information about, and the presence of, detailed procedures for safety policy and care practices showed good results. The main weak points were a deficit in IT support and a lack of procedures in the SMD cycle. The hospital pharmacist was shown to be a key figure in the multidisciplinary team.

\section{ВЪВЕДЕНИЕ}

Съгласно Европейските указания за квалификацията и класификацията на софтуера, използван самостоятелно в медицинските грижи в нормативната уредба на медицинските изделия, медицинско изделие (МИ) е всеки инструмент, апарат, принадлежност, софтуер, материал или друг продукт, използван сам или в комбинация, заедно с всички аксесоари, включително софтуера, предназначен от неговия производител да бъде използван специално за диагностика и/или терапевтични цели и необходими за неговото прилагане, предвиден от производителите да бъде използван за хората със следните цели: диагностика, профилактика, мониторинг, лечение или облекчаване на заболяване; диагностика, мониторинг, лечение, облекчаване или компенсиране на нараняване или недъг; изследване, заместване или модифициране на анатомията или на физиологичен процес; контрол на раждаемостта, и което не постига своето основно предназначение в или върху човешкото тяло чрез фармакологични, имунологични или метаболични средства, но което може да бъде подпомогнато в своята функция по такъв начин.“ (1).
Стерилните медицински изделия (СМИ) включват изделия като превръзки, имплантируеми изделия и хирургически инструменти. Предвид техните особености, управлението им е сложно и изисква добри знания.

Управлението на СМИ е свързано с различни рискови фактори, както присъщи, така и външни. Първият вид зависи от характеристиките на продукта; във втората група попада използването на СМИ, което не отговаря на добрите професионални практики в областта на здравеопазването и/или слабости от комуникационен или организационен характер, които могат да доведат до нежелани събития (2).

Всяка стъпка в цикъла на СМИ - анализ на запитване, закупуване, заявка, получаване, съхранение, издаване, транспорт, експедиция, използване, връщане (рекламация) и контрол - е ключов фактор, който може да окаже влияние върху доброто управление на СМИ (2-4).

Сложността на управлението на СМИ, неспазването на професионални и/или добри организационни практики, комуникационни проблеми (2) и участието на няколко здравни специалисти (2-4) 
допринасят за повишаване на риска. Във Франция управлението на използването на СМИ в болници се извършва от болничната аптека.

Високата вероятност от грешки налага подлагането на управленските методи на оценка, за да се установят слабостите и да се предложат решения. С оглед на това клиничният одит може да е ефективен (5). Демонстрирано е, че грижите за пациентите се подобряват с прилагането на клиничен одит $(6,7)$, че редовно следва да се извършват клинични одити (8), и че с помощта на такива одити се открояват критични моменти в конкретни процедури, в които участват различни здравни професионалисти (6 9). В частност се демонстрира, че фармацевтите са ключов участник в мултидисциплинарните одити $(9,10)$.

Във Франция Националната агенция за подкрепа на работата на здравните и медико-социалните заведения (Agence Nationale d'Appui à la Performance des établissements de santé et médicosociaux - ANAP) е разработила инструменти в помощ на здравните професионалисти за подобряване на дейността на болниците, като например Диагностичния инструмент за СМИ (на фр. Outil Diagnostic Dispositifs Médicaux Stérile) (2). Той представлява одит, позволяващ на персонала да оценява цикъла на СМИ, както в болничната аптека, така и в отделенията.

Средството за самооценка включва следното:

1. Определяне на безопасността на процеса за отстраняване на установени слабости.

2. Насърчаване на обмяна на информация сред професионалистите в мултидисциплинарния екип.

3. Насърчаване на култура на споделяне на техники за безопасност.

4. Осигуряване на работещите в тези области съдържателни планове на принципа на подход ,отдолу-нагоре“.

5. Определяне на приоритети за подобрение.

В настоящото изследване прилагаме пет основни елемента от самооценката на Болничния център в Кан, Франция (на фр. Centre Hospitalier de Cannes), изпълнявайки указанията на ANAP. Целта беше да се демонстрира важността на ролята на фармацевта при управлението на СМИ и в мултидисциплинарните екипи, както и да се представи нагледно одитът на ANAP, поради факта, че броят публикувани одити в областта на медицинските изделия (МИ) е много малък.

\section{МЕтоди}

Методологията на ANAP беше използвана за самооценка. Диагностичният инструмент за СМИ дава достъп до пълните данни. 2 ANAP е дала разрешение за публикуване на използваните данни.

\section{Описание на въпросника}

Одитите са два вида: в болничната аптека и в специализираното отделение, в което често се използват СМИ. На уебсайта на ANAP са посочени въпросите от въпросника (2). Фигура 1 показва извадка от въпросника.

Въпросникът, предназначен за болничната аптека, се състои от две части: Политика на здравното заведение за безопасността в областта на цикъла на СМИ и Цикъл на СМИ в отделението. Въпросникът за отделението също е в две части: Цикъл на СМИ в отделението и Практики на медицинска грижа и тяхното оценяване. Всяка част от двата одита отговаря на определена тема. Всяка тема е с подтеми, описващи стъпка в цикъла на СМИ. Цялостният процес е показан подробно в Таблица 1 (2) В пояснителните бележки към таблицата е дадено описание на темите и подтемите.

Форматът на одита позволява въвеждане в Ексел.

Четири са възможните отговори: „изцяло да“; „донякъде да“; ,„не“; 'НП (неприложимо)'. Всеки отговор носи определен брой точки, изчислен с помощта на математическа формула. В частност отговорът ,донякъде да““ е равен на 0.5 точки, а „НП“ на 0. Неговото използване трябва да е строго ограничено и основателно (2).

След като се попълнят клетките, автоматично се генерира скоринг, в числово изражение на общ брой точки и като относителен дял в проценти. Също така се използва и графика тип радарен екран за нагледно представяне на данните. По лъчи,

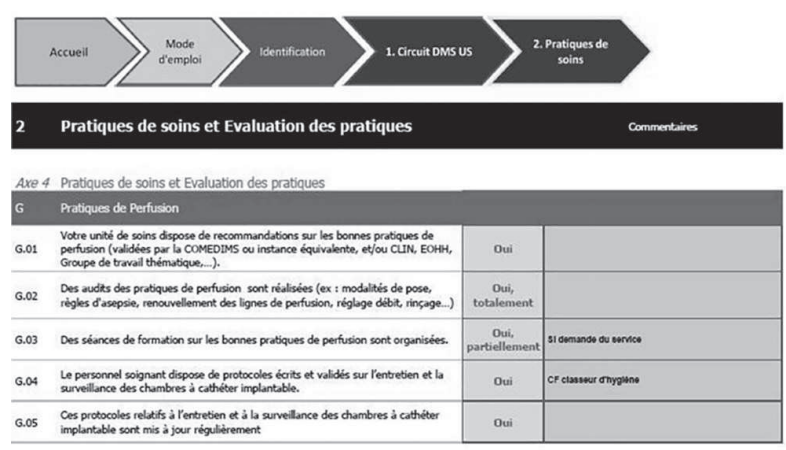

Фигура 1. Извадка от одита за болнично отделение на ANAP 
Таблица 1. Схема на структурата на инструмента на АNAP(1) *

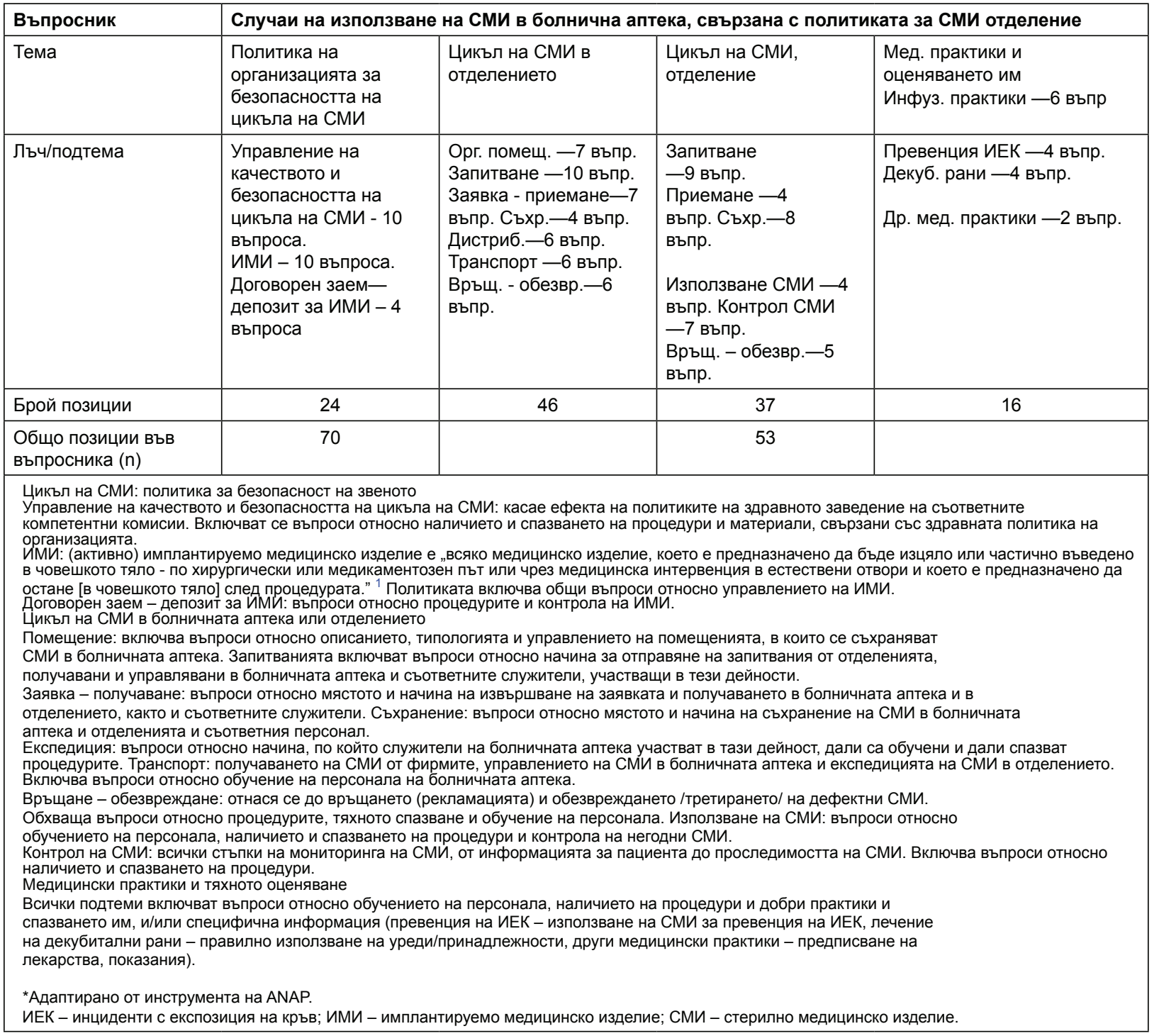

излизащи от общ центьр, са дадени различни количествени променливи, и се генерира схематично представяне на слабите и силните моменти в същия шийт, като веднага се откроява тенденцията в управлението на СМИ.

В одита се определят следните стойности за различната степен на контрол на риска: 0-33\% „слаб контрол на риска“, 34-66\% „среден контрол на риска“, 67-100\% „висок контрол на риска“. Определени са следните положения:

- Верифициране на състоятелността на позициите във въпросника, за да се избегне превратно тълкуване;

- Обогатяване на съдържанието на въпросника с други елементи, ако е необходимо;
- Оценяване на спазването на тези процедури;

- Осигуряване на прилагането на процедурите (2).

\section{Провеждане на одита}

Одитьт се проведе през август 2013 г. в Болничния център на Кан (11), Франция. Организацията представлява болница за активно лечение с 827 легла, 8 медицински центъра, 39 болнични услуги и 1800 служители (12).

През 2013 г. общо 1850 заявки за СМИ са обработени от болничната аптека.

За целите на одита бяха привлечени следните служители: (1) в болничната аптека: началникът на аптеката, още един фармацевт, един стажант, двама помощник-фармацевти, които са квалифицира- 
Таблица 2. Резултати за болничната аптека

\begin{tabular}{|c|c|c|c|c|c|c|c|}
\hline \multirow{2}{*}{\multicolumn{2}{|c|}{ Няма контрол }} & \multicolumn{3}{|c|}{ Ниво риск } & \multirow{3}{*}{$\begin{array}{l}\text { \% контр. на } \\
\text { риска } \\
67\end{array}$} & \multirow{3}{*}{$\begin{array}{l}\begin{array}{l}\text { Одитно } \\
\text { ниво }\end{array} \\
\text { Високо }\end{array}$} & \multirow{3}{*}{$\begin{array}{l}\text { Постигнат } \\
\text { рез. }\end{array}$} \\
\hline & & \multirow{2}{*}{$\begin{array}{l}\text { Има контрол } \\
6\end{array}$} & \multirow{2}{*}{$\begin{array}{l}\text { Общо } \\
22\end{array}$} & \multirow{2}{*}{33} & & & \\
\hline 1 & Политика на орг. за безоп. на цикъла на СМИ & & & & & & \\
\hline A & Управл. качеств. и безоп. на цикъла на СМИ & 2 & 7 & 9 & 78 & Високо & 3 \\
\hline B & ИМи & 2 & 12 & 17 & 71 & Високо & 3 \\
\hline C & Договорен заем-депозит за ИМИ & 2 & 3 & 7 & 43 & Средно & 2 \\
\hline 2 & Цикъл на СМИ в болн. аптека & 13 & 38 & 56 & 68 & Високо & 3 \\
\hline Лъч 2 & Помещения & 0 & 7 & 7 & 100 & Високо & 3 \\
\hline D & Помещение болн. аптека & 0 & 7 & 7 & 100 & Високо & 3 \\
\hline Лъч 3 & Запитване - заявка - приемане & 4 & 19 & 24 & 79 & Високо & 3 \\
\hline $\mathrm{E}$ & Запитване & 2 & 12 & 14 & 86 & Високо & 3 \\
\hline $\mathrm{F}$ & Заявка - приемане & 2 & 7 & 10 & 70 & Високо & 3 \\
\hline Лъч 4 & Съхранение, експедиция, транспорт & 7 & 10 & 21 & 48 & Средно & 2 \\
\hline G & Съхранение & 2 & 2 & 5 & 40 & Средно & 2 \\
\hline $\mathrm{H}$ & Експедиция & 1 & 6 & 8 & 75 & Високо & 3 \\
\hline 1 & Транспорт & 4 & 2 & 8 & 25 & Ниско & 1 \\
\hline Лъч 5 & Връщане - обезвреждане & 2 & 2 & 4 & 50 & Средно & 2 \\
\hline $\mathrm{J}$ & Връщане - обезвреждане & 2 & 2 & 4 & 50 & Средно & 2 \\
\hline
\end{tabular}

СМИ, стерилни медицински изделия.

ни професионалисти по фармация и един складов работник; (2) в отделението: началникът на болничната аптека, стажантьт от болничната аптека и главната сестра в отделението за коремна, съдова и урологична хирургия.

Това отделение е за пациенти за операция на артерии и вени, както и пациенти за хемодиализа. Сред рутинните операции са: аневризма на корем-

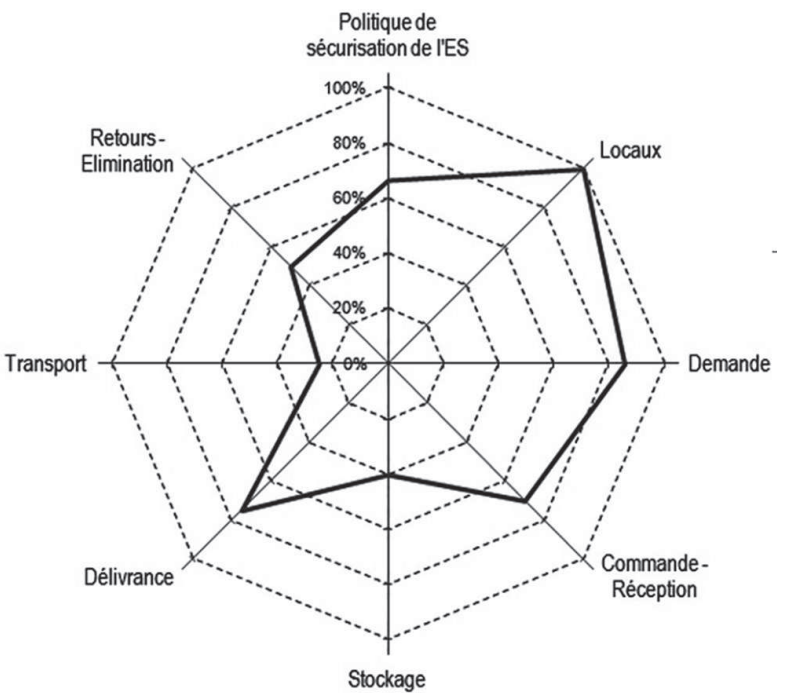

Фигура 2. /по часовн. стрелка, от начало позиция „12 ч. “/: Графика на обобщените резултати, болн. аптека. Политика на орг. за безопасност, Помещения, Запитване, Заявка-получаване, Съхранение, Експедици, Транспорт, Връщане - обезвреждане. ната аорта, разширяване на илиачната или феморалната каротидна [артерия], интервенции при разширени вени, техники за ендолуминално разширяване и поставяне на стент на артерио-венозни фистули за управлението на хронична бъбречна недостатъчност (13). През 2013 г. броят пациенти, хоспитализирани за операция в отделението за коремна, съдова и урологична хирургия е 2393 (съдова хирургия 432, урологична хирургия 849, коремна хирургия 1112), с болничен престой на 3068 пациенти (съдова хирургия 541, урологична хирургия 1228, коремна хирургия 1299). Броят обработени заявки с СМИ е 1110 (230 хирургически СМИ, 880 СМИ за операционната зала).

Резултатите автоматично излизат в шийтове в Майкрософт Ексел.

\section{Резултати}

Първоначално данните се събират в аптеката, след което в отделението. Дават се отговори на всички въпроси.

\section{Въпроси, предназначени за болничната ап-} тека

Общо въпросите са 70 за всички 123 позиции (57\%) във въпросника за болничната аптека, като 24 се отнасят до политиката за безопасността на 
Таблица 3. Резултати за отделението

\begin{tabular}{|c|c|c|c|c|c|c|c|}
\hline \multirow{2}{*}{\multicolumn{2}{|c|}{ Няма контрол }} & \multicolumn{3}{|c|}{ Ниво риск } & \multirow{3}{*}{$\begin{array}{l}\text { \% контр. } \\
\text { на риска } \\
64\end{array}$} & \multirow{3}{*}{$\begin{array}{l}\begin{array}{l}\text { Одитно } \\
\text { ниво }\end{array} \\
\text { Средно }\end{array}$} & \multirow{3}{*}{\begin{tabular}{|l|} 
Постигнат \\
резултат
\end{tabular}} \\
\hline & & \multirow{2}{*}{\begin{tabular}{|l|} 
Има контрол \\
12 \\
\end{tabular}} & \multirow{2}{*}{\begin{tabular}{|l|} 
Общо \\
36 \\
\end{tabular}} & \multirow[b]{2}{*}{56} & & & \\
\hline 1 & Цикъл на СМИ в отделението & & & & & & \\
\hline Лъч 1 & Запитв. - получ. - съхр. Сми & 8 & 16 & 29 & 55 & Средно & 2 \\
\hline A & Запитване & 2 & 7 & 10 & 70 & Високо & 3 \\
\hline B & Получаване & 2 & 3 & 6 & 50 & Средно & 2 \\
\hline C & Съхранение & 4 & 6 & 13 & 46 & Средно & 2 \\
\hline Лъч 2 & Използване - контрол на СМИ & 2 & 16 & 20 & 80 & Високо & 3 \\
\hline $\mathrm{D}$ & Използване на СМИ & 1 & 4 & 6 & 67 & Високо & 3 \\
\hline $\mathrm{E}$ & Контрол на СМИ & 1 & 12 & 14 & 86 & Високо & 3 \\
\hline Лъч 3 & Управл. на върнати СМИ и обезвреждане & 2 & 4 & 7 & 57 & Средно & 2 \\
\hline $\mathrm{F}$ & Управление на връщане и обезвр. СМИ & 2 & 4 & 7 & 57 & Средно & 2 \\
\hline 2 & Мед. практики и оценяването им & 0 & 21 & 24 & 88 & Високо & 3 \\
\hline Лъч 4 & Мед. практики и оценяването им & 0 & 21 & 24 & 88 & Високо & 3 \\
\hline G & Инфузионни практики & 0 & 8 & 9 & 89 & Високо & 3 \\
\hline $\mathrm{H}$ & Превенция на ИЕК & 0 & 5 & 6 & 83 & Високо & 3 \\
\hline 1 & Декуб. рани & 0 & 7 & 7 & 100 & Високо & 3 \\
\hline $\mathrm{J}$ & Други мед. практики & 0 & 1 & 2 & 50 & Средно & 2 \\
\hline
\end{tabular}

ИЕК - инцидент с експозиция на кръв; СМИ - стерилно медицинско изделие.

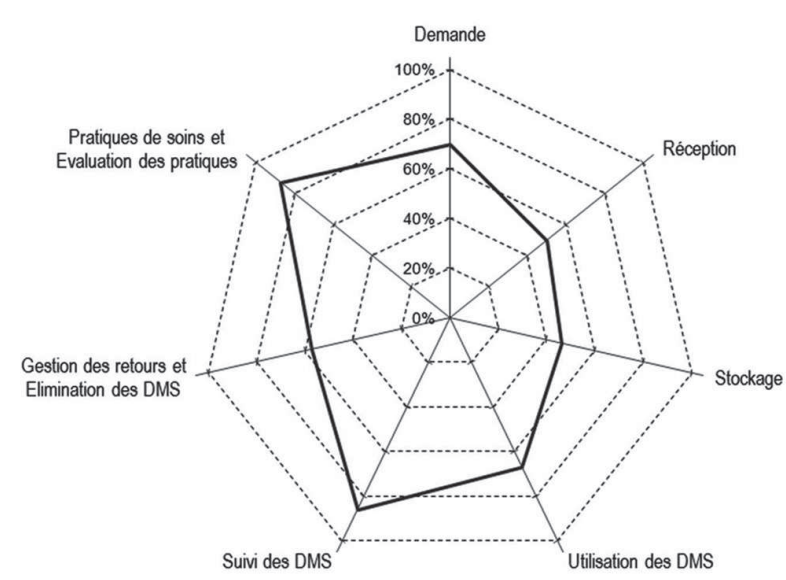

Фигура 3. /по часовн. стрелка, от начало позиция „12 ч. “/: Графика на обобщените резултати, отделение. СМИ. Запитване, Получаване, Свхранение, Използване на СМИ, Контрол на СМИ, Управление на върнати СМИ и обезвреждане, Мед. практики и оценяването им.

здравното заведение за СМИ и 46 - до цикъла на СМИ в болничната аптека.

Таблица 2 показва стойностите на [контрола на] риска за всяка тема и подтема, нивото на спазване на стандартите за одит и общия резултат, постигнат за всяка област. Фигура 2 графично представя резултатите за всяка тема и подтема. Таблица 2 показва относителния дял в проценти. В болничната аптека цялостният контрол на риска отразява нивото на спазване на изискванията за одита (средна величина 67\%), сьгласно броя точки в двете теми
(Политика на организацията за безопасност на цикъла на СМИ - 67\%, Цикъл на СМИ в болничната аптека - Таблица 2). Така резултатьт отразява нивото на спазване на стандартите за одита.

В частност се получи висок резултат за контрола на риска по темата „политика на организация за безопасността на цикъла на СМИ““ $(68 \%)$. Степента е висока за „Управление на качеството и безопасността на цикъла на СМИ“ (78\%) и „Имплантируеми МИ“ (ИМИ; 71\%), но е средна за „Договорен заем - депозит за ИМИ“ (43\%), което значително намалява общия резултат.

По тема „Цикъл на СМИ в болничната аптека“ (68\%) резултатите са следните: организация на помещението (100\%) „висок“, запитвания (86\%) „висок“, заявки - получаване (70\%) „висок“, „сьхранение“ (40\%) „среден“, експедиция (75\%) „висок“, транспорт (25\%), „нисък“, връщане - обезвреждане $(50 \%)$,среден“. Така по-добрите резултати в цикъла на СМИ са във връзка със запитването и фазата „заявка-получаване“. Резултатьт е висок и за организацията на помещението, но не и за съхранението. Доброто съхранение в склада е свързано с подходящо помещение/материална база, но въпреки добрите стандарти за последното, процедурите за съхранение са слаби (два от четири въпроса получиха отрицателен отговор). Два от шест въпроса относно транспорта бяха с отрицателен отговор поради липса на процедури и на анализ на анома- 
Таблица 4. Основни комисии във френски държавни лечебни заведения

\begin{tabular}{|c|c|}
\hline Орган & Компетентност \\
\hline $\begin{array}{l}\text { Комисия за } \\
\text { предотвратяване на } \\
\text { болнични инфекции (Comité } \\
\text { de Lutte contre les Infections } \\
\text { Nosocomiales-CLIN). }\end{array}$ & $\begin{array}{l}\text { Отговаря за предоставяне на } \\
\text { информация за надлежното из- } \\
\text { ползване на продукти, извършва } \\
\text { одити и разпространява инфрор- } \\
\text { мация. }\end{array}$ \\
\hline $\begin{array}{l}\text { Комисия за лекарства } \\
\text { и СМИ (Commission } \\
\text { du Médicament et des } \\
\text { Dispositifs Médicaux } \\
\text { Stériles_COMEDIMS) }\end{array}$ & $\begin{array}{l}\text { Разработва и актуализира на- } \\
\text { ръчника за лекарства и СМИ, } \\
\text { разработва препоръки за пра- } \\
\text { вилно назначаване на лекарства } \\
\text { и СМИ; определя, съвместно със } \\
\text { здравните професионалисти, } \\
\text { терапевтичните приоритети в } \\
\text { полза на последователни лекар- } \\
\text { ствени политики. }\end{array}$ \\
\hline $\begin{array}{l}\text { Комисии за } \\
\text { лечебните заведения } \\
\text { (Commission médicale } \\
\text { d'établissement- }\end{array}$ & \multirow{3}{*}{$\begin{array}{l}\text { Разработва програми за качество } \\
\text { и безопасност на мед. практики, } \\
\text { вкл. СМИ. }\end{array}$} \\
\hline CME) & \\
\hline $\begin{array}{l}\text { СМИ, стерилно } \\
\text { медицинско изделие. }\end{array}$ & \\
\hline
\end{tabular}

лиите. По отношение на транспорта и връщането и обезвреждането отсъстваха добри процедури.

Най-големите пропуски не се отнасят до неспазване на професионални добри практики или до организационни и комуникационни въпроси, а по-скоро до непълнота на инструменти за предотвратяване на външни рискове.

\section{Въпросник, предназначен за отделението}

50 от всички 123 (43\%) въпроса са за отделението: 37 за цикъла на СМИ в отделението и 16 за медицинските практики и тяхната оценка.

В Таблица 3 са дадени показателят за контрол на риска и процентните дялове, както и броят точки за всяка тема и подтема. Резултатьт за управление на „Цикъл на СМИ в отделението“ (64\%) е понисък от този за болничната аптека (съответно 2 и 3), докато резултатите са високи за „Медицински практики и тяхното оценяване“ (88\%).

Фигура 3 представя графично резултатите.

За „Цикъл на СМИ в отделението“ одитът установява средно ниво, получено както следва: запитване (70\%) „високо“, получаване (50\%) „средно“, съхранение (46\%) „средно“, използване на СМИ (67\%) „високо“, контрол на СМИ (86\%) „високо“, управление на върнати изделия и обезвреждането им (57\%) „средно“. Различията в резултатите за отделните стьпки са видими. Отсъствието на процедура е един от най-съществените пропуски (1/7 въпр. по контрол на СМИ, 2/5 въпр. по управле- ние на връщането и обезвреждането на СМИ), но са налице и някои организационни слабости, като нерегулярен контрол на обезвреждането. Налице е обаче добра комуникация между отделението и болничната аптека.

Постигнат е висок резултат по отношение на „Медицински практики и тяхното оценяване“. Общият резултат по компоненти е както следва: „инфузионни практики“ (89\%) „високо“, предотвратяване на инциденти с експозиция на крьв (ИЕК - 83\%) „високо“, лечение на декубитални рани (100\%) „високо“, други медицински практики $(50 \%)$ „средно“. Добрите резултати за тези подтеми са благодарение на високото ниво на спазване на добри професионални практики.

\section{Дискусия}

След одита се извърши преглед на управлението на СМИ.

\section{Политика на организацията за безопасност на цикъла на СМИ}

Резултатите показват, че политиката за безопасността е задоволителна и значително по-добра в сравнение с тази в други френски лечебни заведения, които също използват одита на ANAP (4).

Силните страни се отдават на наличието на няколко комисии, дейността по управление на риска и управлението на ИМИ.

Комисиите имат различни отговорности: разработване на процедури за надлежно използване и обезвреждане на СМИ, информация за специалистите, извършващи назначението на МИ, относно контрола на използването на ИМИ, разписване на конкретни протоколи относно негодността на ИМИ. В Таблица 4 са посочени основните комисии във френски болници и компетентността им относно СМИ.

Управлението на риска се утвърждава като фактор с изключителна важност. За по-нататъшното му развитие е създадена система от консултанти и за набиране на информация относно нежелани събития, свързани с използваните СМИ. Всички предупредителни сигнали се обсьждат на мултидисциплинарни срещи.

Нещо повече: бдителността относно МИ е активна част от управлението на риска за здравето. За укрепване на дейността е въведена система за регистриране и събиране на информация за нежелани събития, свързани с цикъла на СМИ. Систе- 
мата е интегрирана в общата политика за управление на риска, свързан с медицинската грижа, като ИМИ се считат за особено важни в този план.

Управлението на ИМИ е ключов фактор при обучението на лекари по темите на надлежното и ненадлежното използване на СМИ, управлявано от информационна система, която не се прилага за други СМИ. За всеки случай на потенциално неуспешно поставяне на ИМИ се сигнализира на болничната аптека. Всяка процедура, свързана с използване на ИМИ, се регистрира и наблюдава от страна на болничната аптека и отделението.

Основните слабости са по линия на отсъствие на процедури относно връщането и обезвреждането на СМИ, както и управлението на СМИ и ИМИ като цяло.

Сред другите важни дейности е стандартизирането на биомедицински средства за инфузия, както и системата от консултанти и управлението на ИЕК.

Цикъл на СМИ в болничната аптека и в отделението

Получените резултати са сравними с данните от обобщителния доклад от 2012 г. за 21 френски здравни заведения, одитирани по ANAP (5).

Одитът представя непосредствена и ясна диагностика, отразяваща реалната ситуация и дава веднага ясен набор от процедури за подпомагане на мултидисциплинарната работа $(2,4)$.

За болничната аптека резултатите по позиция „заявка - получаване“ и „съхранение“ са по-високи от тези за други болници; в същото време се отчитат по-ниски резултати за „транспорт“ и „връщане на СМИ“. За отделението по показателите за приемане и контрол на СМИ изглежда разлика няма в сравнение с други болници, докато по отношение на запитвания и използване на СМИ резултатите са по-високи за съхранението и по-ниски за връщането на СМИ (4).

По-големият брой точки е възможно да се дължи на наличието на помещения в зона с контрол на достыпа - по-специално контролирано влизане в болничната аптека, както и на обособени зони, в които рутинно се извършват основните дейности (т. е. получаване, съхранение и експедиция). Надлежно приемане и складиране на СМИ е възможно благодарение на подходящи помещения (както в болничната аптека, така и в отделението), което гарантира добро съхранение и поддържане на всички продукти. Това е важно и по отношение на дейностите, свързани с връщането на СМИ на доставчиците: СМИ, подлежащи на връщане, следва да се съхраняват отделно от другите СМИ.

Също така, за осигуряването на надлежни условия за съхранение на продуктите в болничната аптека служители редовно провеждат специални проверки, а в отделението се спазват изискванията за съхранение.

Наличието на наръчник за СМИ е инструмент от основно значение за лекарите и сестрите при поръчката на продукти. В допълнение болничната аптека надлежно уведомява отделението за промени в пазарната конюнктура.

Неблагоприятните резултати главно се дължат на липса на процедури и недостатъчна компютъризация, както в болничната аптека, така и в отделението. Положението е сходно в други френски здравни заведения (11).

Важна е ролята на непрекъснатото обучение и предоставяне на информация както в болничната аптека, така и в отделението. Това способства за надлежно попълване на складовите наличности и използване на СМИ от медицинския персонал. Периодично се провеждат опреснителни курсове за болничните фармацевти, помощник-фармацевтите, медицинския/сестринския персонал.

Болничният фармацевт изпълнява ключова роля, като ресурс на жизненоважна и актуална информация, както и за надлежния контрол на използването на СМИ.

Също така централизирането на управлението на СМИ от болничния фармацевт е залог за по-добър контрол на риска и подобрено взаимодействие между персонала. Участието на болничния фармацевт в клиничния одит е важно и следва да се реорганизира в мултидисциплинарните екипи (напр. комисията за оценка на качеството).

Медицински практики и тяхното оценяване

Резултатите, отчетени тук, са по-високи от резултатите на други френски лечебни заведения (4). Противно на данни от предишни одити, по-високите резултати се дължат на наличието на конкретни процедури и протоколи за добри перфузионни практики, предотвратяване на ИЕК, лечение на декубитус и други медицински практики, като уринарна катетеризация, трахеална аспирация, гастростомия, хемостатични периоперативни практики и всички практики, характерни за конкретното отделение. 
На пациентите се дава информация относно управлението на имплантируеми изделия, с карта за идентифициране на ИМИ.

Прецени се, че оценяването на най-добро използване на ИМИ за цели, различни от оригиналното им предназначение при необходимост, не е приложимо.

\section{Ограничения}

Едно от ограниченията на анализа е поради недостатъчните данни.

Друг подобен фактор е по линия на сравнимостта на резултатите на други френски болници поради непълните сведения.

\section{Извод}

Клиничният одит беше ефективен и в съответствие с основните цели на $\operatorname{ANAP}(2,4)$.

Какво е известно до момента по темата

- Чрез клиничните одити се подобрява грижата за пациентите.

- Необходимо е да се прилагат одити в болничните услуги.

- Управлението на МИ е сложно и е свързано с множество рискови фактори.

Каква добавена стойност носи настоящото изследване

- Описват се предимствата на одита на управлението на СМИ.

- Дава се пример на анализ на цикъла на СМИ, предвид липсата на публикувани доклади по темата.

- Демонстрира се важността на мултидисциплинарното сътрудничество.

- Демонстрира се ключовата роля на болничния фармацевт.

- Представя се интересен опит в международен контекст.

Благодарение на процедурата за самооценка се открояват най-значимите въпроси в областта на цикъла на СМИ, като се отдава предпочитание и се демонстрира целесъобразността на мултидисциплинарното сьтрудничество $(6,7)$.

Също така болничната аптека се утвърждава като авторитет за всички здравни специалисти и органи, както и като свързващо звено между различните заинтересовани страни. Ролята на болничния фармацевт е централна за задоволяването на различните нужди и за контрол на процедурите.
Бъдещите ни цели включват подобряване на управлението на СМИ и преодоляване на пропуските, както и удостоверяване на настоящите данни с помощта на бъдещ одит. Също така се проучва възможността за осъществяване на одит и в други отделения.

\section{БЛАГОДАРНОСТИ}

Авторите изказват благодарност на проф. Марина Гаярте и д-р Джанлука Милио, Факултет по фармация и технология на лекарствата, Университет в Торино, за рецензирането на статията.

Организации с принос: VV - при събиране и анализ на данните и обсъждане на резултатите, подготовка и изготвяне на ръкописа и утвърждаване на окончателната му версия. AF-G - при събиране на данни и обсъждане на резултатите; получаване на разрешение от ANAP за публикуване на данните, утвърждаване на окончателната версия на ръкописа; CВ - при промотиране на използването на одита на ANAP, събиране на данни, обсъждане на резултатите.

\section{КОНКУРЕНТНИ ИНТЕРЕСИ - НЕ СА НАЛИЦЕ}

Удостоверяване на източници и вътрешна рецензия - не е възлагано; проведена е външна рецензия.

\section{ИЗПОЛЗВАНИ ИЗТОЧНИЦИ}

1. Medical devices - European Commission. http://ec.europa. eu/health/medical-devices/ files/meddev/2_1_6_ol_en.pdf (accessed 15 Apr 2015).

2. Sécuriser le cycle des Dispositifs Médicaux Stériles dans les Etablissements de Santé. http://www.anap.fr/publicationset-outils/outils/detail/actualites/securiser-le-cycle-desdispositifs-medicaux-steriles/ (accessed 20 Aug 2013).

3. Sécurisation du cycle des dispositifs médicauxen etablissements de sante, Outil Inter Diag Dispositifs Médicaux Stériles. http://www.euro-pharmat.com/ documents/ journees_lille/conferences_lille/15oralelille.pdf (accessed 30 Dec 2014).

4. Sécurisation du cycle des Dispositifs, Médicaux en Etablissements de Santé, Outil Inter Diag Dispositifs Médicaux Stériles. http://www.jiqhs.fr/wp-content/uploads/ 2012/12/AT15_TALLA_ANAP_Inter-Diag_DispositifsM\%C3\%A9dicaux-St\%C3\%A9riles_jiqhs2012.pdf (accessed 30 Dec 2014).

5. Management of Medical Devices. Areas requiring further strengthening, global forum on medical devices, Bangkok, 2010. http://www.who.int/medical_devices/ 03_medical devices_management_david_porter.pdf (accessed 28 May 2015). 
6. A guide to clinical audit - Appendix7. http://psnc.org.uk/ wp-content/uploads/2013/ 07/a_guide_to_clinical_audit.pdf (accessed 20 May 2014).

7. Ministero della Salute Italiano, Dipartimento della qualita“ direzione generale della programmazione sanitaria, dei livelli essenziali di assistenza e dei principi etici di sistema, l'audit clinico. http://www.salute.gov.it/imgs/C_17 pubblicazioni_1552_allegato.pdf (accessed 6 Jan 2015).

8. Maripuu H, Mamoon AA, Kearney MP. An audit of antimicrobial treatment of Нискоеr respiratory and urinary tract infections in a hospital setting. Eur J Hosp Pharm 2014;21:139-44.

9. Dodds LJ. Pharmacist contributions to ensuring safe and accurate transfer of written medicines-related discharge information: lessons from a collaborative audit and service evaluation involving 45 hospitals in England. Eur J Hosp Pharm 2014;21:150-5.

10. Brøndgaard Nielsen L, Croft Buck T. Clinical pharmacy: developing the role of the pharmacists. Eur J Hosp Pharm 2012;19:547-8.

11. Audit des systemes d'information hospitaliers aupres d'etablissements representatifs, rapport final, May 2014. http://www.anap.fr/publications-et-outils/publications/ detail/actualites/audit-des-systemes-dinformationhospitaliers-aupres- detablissements-representatifs/ (accessed 31 May 2015).

12. Centre Hospitalier de Cannes. http://www.ch-cannes.fr/ centre-hospitalier-de- cannes-3.html (accessed Jan 2015).

13. Centre Hospitalier de Cannes. http://www.ch-cannes. $\mathrm{fr} /$ patients-et-visiteurs/notre-offre-de-soins/chirurgievasculaire-277.html (accessed Apr 2015).

Адрес за кореспонденция:

Dr Annie Fagot-Gandet,

Hospital Centre of Cannes

(Centre Hospistalier de

Cannes-CH Cannes), 15

Avenue des Broussailles-CS

50008, Cannes 06414, France;

a.FAGOT-GANDET@ch-cannes.fr 